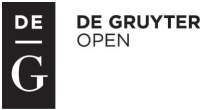

\title{
Territorial Self-Governing Units of THE Czech RePUblic aS ENTIties Possessing OWNership AND Other Proprietary Rights (THE BASIC CONCEPTUAL ISSUES)
}

\author{
Petr Havlan ${ }^{1}$, Jan Janeček ${ }^{2}$
}

\begin{abstract}
The property owned by self-governing units represents an important socioeconomic factor with the potential to affect a wide range of aspects of life, considering the scope of self-governing units.

The aim of this paper is to present an overview of the recent legal regulations regarding the proprietary position of Czech self-governing units (municipalities and regions) as well as comments on their development (considering wider circumstances) from 1990 to the present day. It focuses on the nature of legal entities sui generis (in Czech called "př́spěvková organizace"), which perform ownership and other proprietary rights of the municipalities and regions on the basis of specific public law relations. Appropriate attention is also dedicated to other legal subjects operating in the sphere of territorial self-government considering their proprietary position. The sub-objectives of the article are the identification and explanation of solutions to the identified problems concerning the analyzed questions.

The methodological part of the article is based on the analysis and critical evaluation of the current state of the discussed legal issues. The authors use the methods of legal hermeneutics to obtain correct interpretations of the analyzed legal regulations.

The entities sui generis in question are found to be a relic of the transition period in Czech legal development after the 1990s and should be replaced with up-to-date forms of a public legal entity.
\end{abstract}

\section{Keywords}

Czech Republic, Ownership, Property, Proprietary Rights, Public Administration, Selfgoverning Units

\footnotetext{
${ }^{1}$ Masaryk University, Faculty of Law, Veveř́ 70, 61180 Brno, Czech Republic. E-mail: Petr.Havlan@law.muni.cz.

${ }^{2}$ University of Hradec Králové, Faculty of Informatics and Management, Rokitanského 62, 50003 Hradec Králové 3, Czech Republic. E-mail: jan.janecek@uhk.cz.
} 


\section{Turning points in the development of public administration in the Czech Republic - brief introduction to the issue}

The "unrestrained" disintegration of local municipalities in the Czech Republic at the beginning of the 1990s resulted in the establishment of dozens of small municipalities which, in principle, lacked economic viability ("independence"). Nevertheless, this forfeiture for unexpectedly attained freedom was understandable. However, developments in the following years, especially at the beginning of the 21 st century, are more difficult to understand.

First of all, it is important to point out that the self-governing regions were established in a number which was problematic and in sizes that were incommensurable. Problems related to their operation, such as, for example, complications in securing continuity and proportionality of flows of "EU monies" to these units, are generally known in the Czech Republic today. But in fact this situation is not surprising. The circumstance, i.e. that the number and sizes of Czech self-governing territorial regions arose as a result of a range of factors which (individually as well as in aggregate) were minimally influenced by the findings of administrative or financial science, in other words, by the knowledge that these sciences had collected as a part of their "theories of reforms of public administration", is actually typical.

Furthermore, the problem of the current form of the "coexistence" of the Czech government (the center) and Czech regional self-governments (regions) - which has been aptly named "the system of carefully organized irresponsibility" - lies in transferring responsibility from the government to the regions - in principle, always when it suits the state - and in renouncing responsibility by the regions - in principle whenever they consider this appropriate or, in other words, favorable. This is well illustrated by the dispute over competencies between Czech regions (specifically the South Moravia Region) and the Czech government concerning the competency to secure an emergency medical service, a dispute that was finally settled by the Constitutional Court of the Czech Republic in its decision of 25 September, 2007, file ref. Pl. ÚS 5/04.

Furthermore, it is worth mentioning that the Czech territorial state administration with general competence was dissolved, i.e. district councils were liquidated. The dissolution of these councils, probably the best working component of the Czech post-November public administration, resulted, among other things, in liquidation of the territorial state administration structure that had been optimized in a natural way (i.e. with respect to the development and the current state of the transportation and telecommunications infrastructure); as almost the state's renouncement of its interest in a territory, which is of course an interest different from (and what is more, irreplaceable with) the interest of municipalities or regions; and also in the "disintegration" of expertise in Czech territorial state administration, which (or the level of which) is lower in municipalities of the third type (with so-called delegated powers) for many reasons, when compared to the former expertise at the liquidated district councils.

\footnotetext{
${ }^{3} \operatorname{Keller}(2003)$.
} 
The cardinal issue then is that all the above, in aggregate, has significantly influenced the form and situation of the "basis of assets" of all Czech public entities, i.e. not only municipalities and regions, but also the state itself, or representatives of "interest based self-governments" such as public service professional chambers or "academic selfgovernments" represented (typically) by public universities. Nevertheless, besides their budget and subsidy or rather tax and levy aspects, the "common denominator" of the abovementioned is their assets or the quantity, quality and structure of this "public property"4.

The authors of this article believe that public ownership in the sense defined above constitutes an irreplaceable socio-economic element that deserves the increased protection of the legislature. The aim of this article is to provide an analysis of current legislation affecting that property, especially issues of legal and organizational arrangements of property in question and its disposing and handling. The authors would like to verify the hypothesis that the current legislation on the property of municipalities and regions insufficiently responds to changes in socioeconomic conditions and so the property lacks sufficient (public-law) protection.

\section{Development of the legal regulations on the property of territorial self-governments in the Czech Republic in brief}

A brief overview of the contemporary development of legal regulations on the property of territorial self-governments should begin with the so-called reconstruction phase, i.e. at the time when state property predominated. Actually, the first theoretical considerations of municipal ownership revival arose before 1989. The concept that was then being considered basically perceived municipal ownership only as an integral part of state ownership, where the objects of this ownership were to be parts of the national property and the subject territorial state and administrative authorities. This means it was a concept in principle compatible with the system of national committees, which was not dissimilar to the regulation stipulated by the Constitution of $1948^{5}$.

What would have happened if the concept had really been implemented? First of all, it would have been a mere illusion of local self-government. Distinctive property, "independent" of the state, i.e. the basic attribute of every self-government or, in other words, something that no real self-government can exist without, would have been lacking.

On the other hand, we would have had available basically consolidated legal regulations stipulating the rules for property management and disposal, although it would have been formally the state's property, nevertheless fulfilling its function in a territory in some way. In other words, it would have been property that would have been in principle (or with some exceptions, as the case might have been) governed by the regulation contained in the Economic Code and the decree implementing it (see Decree No. 119/1988 Coll., on the administration of national property).

\footnotetext{
${ }^{4}$ Havlan (2008) or Havlan, Janeček (2009).

${ }^{5}$ Havlan (2008).
} 
Developments in the 1990s brought a fundamental change not only in that they led to the establishment of real municipal self-government, based on its own distinctive (i.e. "independent" from the state) municipal property obtained both from the state and subsequently through activities performed by municipalities themselves, but also in that the consolidated legal regulations stipulating the rules for management and disposal of the property of the given local self-governments was renounced ${ }^{6}$.

The trend continued at the beginning of the 21st century through the creation of real regional self-governments, when the established regions obtained (similar to the municipalities) their own distinctive (i.e. "independent" from the state) property from the state, through activities performed by the regions themselves, or in another legal way, and through a further "deepening" of the renouncement of consolidated legal regulations stipulating the rules for management and disposal of the property owned by both types of territorial self-governing units existing in the given phase. It is no exaggeration to say that the latter is a missed historical opportunity, because the originally considered bill on the "property of territorial self-governing units" was not approved when, basically, further "attempts" were abandoned after the first unsuccessful attempt by the Ministry of Finance of the Czech Republic.

And what is the present like? The general issues concerning property rights of territorial self-governing units - contrary to those concerning the state where the situation may be characterized as satisfactory, especially thanks to Act No. 219/2000 Coll., on the property of the Czech Republic and its performance in legal relations, as amended, although the level of the legal regulation that has been reached is not anywhere near the level that could and should be reached - are non-conceptually contained in some regulations of the currently effective Act No. 128/2000 Coll., on municipalities (the Municipal Order hereinafter "MO"), Act No. 129/2000 Coll., on regions (the Regional Order - hereinafter "RO"), and also Act No. 131/2000 Coll., on the capital city of Prague, as well as (in a certain sense especially) in some provisions of Act No. 250/2000 Coll., on budgetary rules of territorial budgets.

The fact that a consolidated act (or, in other words, some alternative to the "State Property Act") is missing, however, makes the current legal regulation of property of Czech territorial self-governing units considerably confused, internally inconsistent and incomplete as regards the scope of governed matters; after all, this is the reason why its application is difficult. Hence, the unsatisfactory state of the legal regulations in question is obvious.

\section{On the current state of legal regulations of property owned by territorial self-governments in the Czech Republic}

Even after more than ten years since the new legal regulation stipulating the status of the territorial self-governing units (hereinafter "TSGU") came into force, the professional public is first of all kept busy eliminating the interpretation problems arising from some provisions of the new Act on Municipalities (No. 128/2000 Coll.) and the Act on Regions

${ }^{6}$ Ibid., 126-127. 
(No. 129/2000 Coll.), as well as some provisions of newly passed related rules and regulations. From among these, let us at least examine "small budgetary rules", i.e. Act No. 250/2000 Coll., on budgetary rules of territorial budgets.

It seems that the core of the abovementioned interpretation difficulties lies, on the one hand, in the legislative wording of a certain hierarchy of bodies inside a respective selfgovernment entity that was not very well done, and on the other hand, on the necessary division of competencies and liabilities among them. Specifically, this concerns the relation between a municipal (regional) council $^{7}$ and a municipal (regional) board ${ }^{8}$. Accordingly, because the legislator did not consistently approach the council as the highest body of the TSGU as regards the separate powers of a municipality, this means that the council is not especially entitled to reserve for themselves the competencies that the law reserves for the board (see s. 102 (2) of the MO and s. 59 (1) of the RO), the respective board is not, "sensu stricto", only the executive body as regards these separate powers. The fact that we also have s. 88 of the MO and s. 38 of the RO here, i.e. provisions enabling a council to cancel decisions of their "board" not only in the event that such a decision is contrary to a legal regulation but also when it is simply contrary to a council's decision, may not be qualified in any terms other than a lack of conception signaling the unclear relations between these two key bodies of TSGU. But in fact it is the property sphere where it is critically important to clear up the relation between the council and the board (i.e. in principle, their decision-making and executive powers).

Of course, legislative "correction" comes into consideration as the best way to solve the above-described state causing problems in practice. All sorts of things may surely be settled by regulations, especially internal (organizational) ones, made by the respective TSGU itself or simply by means of reasonable common proceedings taken by both interested bodies.

Despite the existing general interpretation efforts that need to be unequivocally appreciated as such, the nature of the matter itself referring to the rights of property remains sidelined. Among other things, this is so because there are problems not only with what and how the regulations provide but also - and sometimes primarily - what has not been provided for although it could and should be.

\section{Entities Possessing the Rights and Executors of the Rights}

There may be no doubt that entities possessing ownership and other proprietary rights are TSGUs themselves (see s. 20 of the Civil Code - Act No. 89/2012 Coll.). Article 101, paragraph 3 of the Constitution of the Czech Republic ["Territorial self-governing units are public law corporations which may own property (in principle things and property rights - authors' note) ..."] as well as s. 2 (1), the first sentence of the MO ("a municipality

\footnotetext{
${ }^{7}$ The municipal (regional) council is a collegiate body of the self-governing territorial unit in question with a direct democratic authorization arising from elections. The number of its members is derived from the number of inhabitants of the territorial self-governing unit.

${ }^{8}$ The municipal (regional) board is an executive body of the collegiate type, members of which are elected from among members of the council by the council.
} 
... has its own property") and s. 1 (4) of the RO ("a region has its own property...") speak unequivocally in this sense.

As regards execution of ownership and other proprietary rights of TSGUs, it is necessary to distinguish among the following types of execution today:

- direct (the proprietary rights in question are executed directly in the name and at the expense of a TSGU by its bodies, including decision-making powers of the council and the board);

- mediated through organizational units (the proprietary rights in question are executed in the name and at the expense of a TSGU through organizational "entities" /see s. 5 of the MO and s. 5 of the RO/ - executors, i.e. by a TSGU's organizational units as establishments without legal personality), and

- mediated through legal entities (the proprietary rights in question are executed through independent legal entities - executors, i.e. by a TSGU's institutions receiving contributions from its budget (in Czech "př́spěvková organizace" - a legal entity sui generis, hereinafter "contributory institution") in the name and at the expense of these institutions).

The current professional literature pays some attention to the first type of the "execution" of proprietary rights. It does so especially, as was mentioned in the introduction hereto, with respect to the reserved powers of councils (this, however, does not include only s. 85 of the MO and s. 36 of the RO) and reserved powers of boards that limit the so-called attraction right of councils by virtue of s. 84 (4) of the MO and s. 37 of the RO, as well as with respect to the issues of so-called residuary clauses (s. 102 (3) of the MO and 59 (3) of the RO), according to which the relevant board makes decisions about other matters (i.e. including proprietary ones) belonging to the independent competence of the relevant TSGU unless they are reserved to the council or unless the council has reserved them for themselves, and related issues regarding the provisions of s. 88 of the MO and s. 38 of the RO. However, because these are only minor problems from the point of view of proprietary rights, although they have considerable practical importance, we will furthermore focus mainly on the second and third types of "executions", or rather executors.

\section{Organizational units of TSGU}

\section{Definition}

The institute of "organizational units of TSGU” ("organizační jednotka celku územní samosprávy" in Czech) represents, as regards proprietary rights, the most important innovation that may be encountered in new legal regulations governing territorial self-governments. ${ }^{9}$ However, the Act on Municipalities and the Act on Regions pay little attention to it. As regards the substance of this matter, the only provisions worth mentioning are those set in s. 9 of the MO and s. 2 (2) of the RO, implying the principal possibility to establish these

\footnotetext{
${ }^{9}$ This is not to say that municipalities would not establish any entities without legal personality in the past, but their current, let's say "legal institutionalization" reflects a completely new light on them exactly as on "organizational units".
} 
units without legal personality. We can obtain most information about organizational units of TSGU in Act No. 250/2000 Coll. First of all, this act once again stipulates (s. 23 (1)) that a TSGU "owns the power, for the purposes of meeting its obligations, especially of making economic use of its property and securing publicly beneficial activities, to establish its own organizational units as its facilities without legal personality..." At the same time, it is this legal "non-personality" mentioned at the end of the quoted text (as well as in the wording of s. 9 of the MO and s. 2 (2) of the RO) that is the fundamental characteristic of organizational units. Also, s. 41 (1) of Act No. 250/2000 Coll. as well as s. 57 (1) and (3) of Act No. 219/2000 Coll., on the property of the Czech Republic. .. , as amended, are to be understood especially within this meaning, i.e. as transitional provisions according to which budget organizations that had been operating on the municipal level as legal entities until then were "transformed" to organizational units of municipalities in question without this distinction, while all their rights and obligations passed over to the municipalities. On the other hand, it is understandable that the transformation of the state's organizational units to organizational units of regions according to s. 3 (see also s. 1 (1) (b)) of Act No. 157/2000 Coll., on the transition of some things, rights and obligations from the property of the Czech Republic to the property of self-governing regions, as amended, does not have this character. In this case the "loss of legal personality" in predecessors of the above first mentioned organizations (institutions fully funded from the state budget) happened on the state level according to respective transitional provisions (see especially s. 51 (1)) of Act No. 219/2000 Coll.

Besides the above, Act No. 250/2000 Coll., in its fourth part, provides for the establishment of organizational units of TSGU, which it bounds (within the context of s. 84 (2) (e) of the MO and s. 35 (2) (j) of the RO) to a decision made by a council, and the compulsory content of the deed of establishment that is issued on this occasion. This also includes the "Financial Management of Organizational Units" section (s. 25) where we find, however, only certain principles of budget management or financial management, as the case may be.

\section{Status and characteristic features}

The fact that organizational units of TSGU are not legal entities and therefore, in principle, legal persons but the very organizational entities (divisions) does not mean that they as such could not enter into legal relations (and, of course, not only into them - see below) albeit in the name and under the responsibility of the respective TSGU. As model situations, the following relations are basically entered into: a) standard ("external") property relations with entities (natural persons and legal entities) outside of the respective TSGU as the subject of ownership and other proprietary rights; b) specific ("external") property relations with entities that execute in their own name and under their own responsibility ownership and other proprietary rights of the respective TSGU (for details on them see the "TSGU's contributory institutions" section), and c) specific ("internal") property relations with other organizational units of the respective TSGU.

With respect to a) it may be noted that the standard ("external") property relations include those situations when an organizational unit of the respective TSGU enters into a relation with another TSGU's contributory institution or organizational unit. It is so because de iure 
it is a relation between the respective TSGU and another TSGU's contributory institution in the first case, and a relation between two different TSGUs in the second case.

With respect to a) and b), it must be added that any acts executed in these relationships are taken under the full name of the respective TSGU (founder) and while stating the name and seat of the respective organizational unit (see s. 26 (a) and (b) of Act No. 250/2000 Coll.) or, as the case may be (in performing a specific legal act), also while stating a person authorized to act on behalf of the organizational unit (see s. 26 (d) of the quoted act).

With respect to c), relationships of an organizational unit of the respective TSGU with bodies of the same TSGU executing ownership and other proprietary rights "directly" may be considered to be a version of specific ("internal") property relations. However, here we do not have in mind any relations of a managing character (see especially s. 102 (2) (b) /or also s. 109 (4) (f) of the MO and s. 59 (1) (i) /or also s. 69 (2) (g) of the RO), that are "specific" in another way, so to say.

The origin (change, termination) of the relations characterized under a) and under b) is associated with common types of contracts (of private law), specifically - by definition especially when the respective TSGU acquires property and when property owned by the TSGU is disposed of. Of course, all these acts are executed within the decision-making powers of a council and board and with respect both to property (i.e. a specific part of the TSGU's property) that is handed over to an organizational unit upon its establishment so that the organizational unit would administer the property with the aim to "use it for its own economic purposes", including "determination of such proprietary rights" that will enable the organizational unit to "properly use the property for the purposes which the organizational unit was established for and to take care of it within the determined powers" (s. 26 (e) and (f) of Act No. 250/2000 Coll.), and necessarily - by definition - also another property of the respective TSGU (or its certain part) that has been for example acquired through the activities of the organizational unit. As regards legal rules "of public law" limiting an organizational unit in its property-related activities, the general provisions of the Act on Municipalities (see especially ss. 38 and 39; compare also ss. 40 and 41) and the Act on Regions (see especially ss. 17 and 18; compare also ss. 19 and 23)) apply here. And also the rules provided for in Act No. 250/2000 Coll. (see especially s. 25) have a specific ("budgetary \& financial") character.

The situation described under c), i.e. where relations come into existence between organizational units of the same TSGU, differs in its quality from the situations under a) and b). Of course, the abovementioned framework, property and "limiting" rules did not disappear; however, the origin (change, termination) of these relations, their form and content are not regulated by law, which in principle means that their specific ("organizational \& proprietary") character is not actually reflected.

To complete the basic picture of TSGU organizational units, it is appropriate to mention that they are divisions that are not accounting units by virtue of the Act on Accounting (s. 24 (1), the second sentence of Act No. 250/2000 Coll.) ${ }^{10}$. As a form of financial management of TSGU sui generis, they are determined for such activities that do not require

${ }^{10}$ For the issue of keeping a separate accounting on some incomes and expenditures, compare s. 26 (g) and (h) of the quoted act. 
a high number of employees, do not need any comprehensive and extensive engineering or other technical equipment, are not internally subdivided by sectors or in another organizational manner, and do not enter into any complex economic or legal relations (the third sentence ibid.) Section 24 (2) and (3) and s. 26 (d) of Act No. 250/2000 Coll. then implies that officers of an organizational unit are employees of its founder (TSGU), unless a specific act provides otherwise; that the head of an organizational unit is appointed by its founder that also determines his or her rights and obligations; and that the deed of establishment must specify the persons authorized to act on behalf of the organizational unit.

\section{Issues and Tasks}

It holds true for the legislation on the status of TSGU organizational units, and by analogy also for the legislation on organizational units of the central government ${ }^{11}$, that the legal regulations "working" with them do not always or sufficiently reflect their fundamental nature, although it is the corresponding rendering in the applicable law that represents a key issue for the further existence and functioning of these specific divisions.

It was mentioned hereinabove that, for example, in principle, a legal regulation of their mutual relations (within the respective TSGU) is lacking, while this means especially the institute of so-called "registration", as it is set forth in Act No. 219/2000 Coll. (s. 19 (1)) and part three of the decree implementing the act (decree No. 62/2001 Coll.) and which regulates disposing of the central government's property between its organizational units. In fact, it is a specific property-administration institute based on an agreement, with its specificity lying especially in the fact that it is (as regards its nature) based on an affirmative expression of will by entities that are primarily organizational and not legal in the literal sense. ${ }^{12}$

As regards problems, the most critical one on the level of the central government appeared to be the moment when the legislator (or the author of subordinate legislation) did not provide for the issues related to the unit without legal personality, the acts of which are "by definition" ascribed to the whole (central government) of which it is a part, but for the issues of the legal entity, specifically the institution fully funded from the state budget defunct as of 1 January, 2001. After all, some elements of this approach on the selfgovernment level are also evident in Part 4 of Act No. 250/2000 Coll., especially in s. 26, stipulating the obligatory content of the deed of establishment of organizational units (see hereunder).

In general, thanks to the shortcomings in legal regulation (which includes a certain paradox in itself), there is sufficient space where it is possible to avoid mistakes in the provisions on TSGU organizational units. It is the space of norm-making by self-governments, both as regards external (generally binding) norms and internal (organizational) norms. The primary task of this type of norm-making is to render an "organizational unit" as an organizational division of its own kind that does not have its own property-related authorizations and obligations, but "only" executes such authorizations and obligations for a territorial

\footnotetext{
${ }^{11}$ Havlan (2001).

${ }^{12}$ For more details on this, see ibid.
} 
self-governing unit. It is more than obvious that this is mainly a problem of regions, cities and other bigger municipalities, and not so much a problem of small municipalities (that, after all, do not have to have any organizational units and still less so any contributory institutions).

\section{TSGU's contributory institutions}

\section{Definition}

TSGU's contributory institutions are an expression of a certain continuity (in principle, they are a follow-up to municipalities' institutions that had existed here by virtue of Act No. 576/1991 Coll., as amended, before 1 January, 2001). The question, however, arises as to whether this continuity is desirable. Neither basic acts providing for territorial selfgovernments pay specific attention to them. This also means that s. 9 of the MO and s. 2 of the RO do not speak expressly about the possibility of establishing a contributory institution as a legal entity of its own kind, but only generally about the possibility "to found and establish legal entities for the purpose of fulfilling their tasks". In fact, only s. 84 (2) (e) of the MO and s. 35 (2) (j) of the RO, stipulating that the council reserves the right to establish and wind up contributory institutions ... and approve their deeds of establishment, mention them expressis verbis. The proper provision for contributory institutions may be found in Act No. 250/2000 Coll. This act, once again in its s. 23 (1) (i.e. under the same conditions as are those stipulated for organizational units), enables TSGUs "to establish contributory institutions as legal entities that usually do not make any profit in their activities". It provides for their origin (including the compulsory content of the deed of establishment), changes and termination (s. 27). In the context of this general provision on the origin of contributory institutions, municipalities were additionally enabled (until 30 June, 2001) to transform (if applicable) their existing budget organizations (in Czech "rozpočtová organizace") to contributory institutions (s. 41 (2)). For the sake of completeness, it is necessary to mention s. 2 of Act No. 157/2000 Coll., providing for the mechanism to transform state institutions receiving contributions from the central government budget to regions' contributory institutions and stipulating, among other things, that a region shall be obliged to issue a deed of establishment containing the essential elements pursuant to Act No. 250/2000 Coll. within three months. In section four of the so-called small budgetary rules, we will furthermore find the "Financial Management of Contributory Institutions" part and the "limiting" rules on concluding contracts for a loan or a credit, taking up the obligation of a surety, and on hire-purchase contracts as well as, in principle, on contracts for purchase of securities, and on providing donations by contributory institutions that are important with respect to the proprietary rights. Therein, considerable and significant attention is also paid to the monetary funds of these institutions. 


\section{Status and characteristic features}

The continuity of contributory institutions was mentioned hereinabove. This means that January 1, 2001, was not a milestone after which their nature would have changed as regards property rights. In brief: contributory institutions have retained their legal personality. The fact that they are legal entities of their own kind finds expression, among other things, in the possibility to enter (once again in a model manner) into the following legal relations:

a) standard ("external") property relations with entities (natural persons and legal entities) outside of the respective TSGU as the subject of ownership and other proprietary rights;

b) specific ("external") property relations with the respective TSGU as the subject of ownership and other proprietary rights (or represented by the respective organizational unit, as the case may be); and

c) specific ("internal") property relations with other contributory institutions of the respective TSGU.

With respect to a) it must be added that property relations are considered to be standard ("external") not only in cases when the respective TSGU's contributory institution enters into this type of relation with other TSGUs (that may be, if applicable, represented by their organizational units) or relations with other TSGU's contributory institutions, but also in cases when this institution enters into relations with other entities that "its" TSGU may establish by virtue of s. 23 (1) of Act No. 250/2000 Coll., i.e. trading companies (joint stock companies and limited liability companies) listed under letter c) as well as public benefit corporations mentioned under letter d) (for details, see the text hereunder).

The "agreement" as set forth under the "TSGU's Organizational Units" section for standard and specific ("external") property relations shall be applied upon the origin, change and termination of these relations. Of course, it is not possible to consider the institute of "registration" (see above).

The characteristic feature of a contributory institution, traditionally and despite the latest changes in the legal regulations (see hereinafter), is its "disability for ownership". This means that it does not (should not) have its own property and that the property it administers is exclusively the property of the TSGU in question. Introductory determination, as it were, of TSGU property that is handed over to a contributory institution so it could "manage" it for its economic purposes is a matter of the deed of establishment [s. 27 (2) (e) of Act No. 250/2000 Coll.]. Accordingly, [the same section, letter f)] it is the deed of establishment where such (proprietary) rights are to be determined that will enable a contributory institution to administer the property that was entrusted to it, including any property obtained through its activities (i.e. the property that an institution, in principle, will obtain later for "its" TSGU) for its own purpose which it was established for (the deed of establishment shall specifically set forth the rights and obligations related to the full, efficient and economically effective use of the property, care taken for its protection, development and improvement, conditions for its investment development, if applicable, and also rules for production and sale of goods if they are the subject matter of an institution's activities, the rights and obligations related to renting, if applicable, 
of the entrusted property to other entities, etc.). Of course, such property of a TSGU is also managed in the event of any supplementary activity of a contributory institution [see letter g) of the quoted paragraph]. And exactly because it is always the property (its part) of a TSGU in question, the general rules limiting (or rather setting parameters for) property-related activities contained in the applicable provisions (see hereinabove) of the Act on Municipalities and the Act on Regions shall apply here, besides the special rules for financial management (especially s. 28 of Act No. 250/2000 Coll.) and special "limiting" rules (ss. 34 to 37 of the quoted act). Also, in this case, everything is framed within the decision-making powers of a council and a board. As regards the status of contributory institutions, it is proper to add that they are established for such activities falling under the competence of the TSGU that are usually non-profitable and the scope, structure and complexity of which require an independent legal personality. S. 27 (3), (4) and (6) of Act No. 250/2000 Coll., then imply that origin, division, merge or wind up of a contributory institution becomes effective on the date determined by its founder in a decision where a founder also determines the extent to which rights and obligations shall be passed over to new or assuming organizations or to a founder itself in case an institute is being wound up; furthermore, these facts as well as data concerning the obligatory content of the deed of establishment, including identification of statutory bodies and the manner in which they act in the name of an institution, are registered in the Gazette of the Czech Republic as well as the fact that a contributory institution is also registered in the Commercial Register.

\section{The latest development, issues and tasks}

It is interesting that the "transitivity" of TSGU's contributory institutions has not been worded in formal and legal terms anywhere in the legal regulations providing for such institutions, as it was worded by the legislator in Act No. 219/2000 Coll., on the property of the Czech Republic... by including the regulation on the central government's institutions (including those receiving contributions from the central government budget) into Part 5, among transitional provisions (pp. 54 to 56) ${ }^{13}$, and where the legislator also stipulated, among other things, that a new institution may be established (...) only in the cases and under the conditions stipulated by a special legal regulation (s. 54 (2), the second sentence before the semicolon). This could lead to the conclusion, until April 2009 when Act No. 477/2008 Coll. came to effect, that contributory institutions were counted on for the future and their property rights related nature lying especially in that has something to do here with so-called other legal entities by virtue of s. 18 (2) (d) of the "old" Civil Code - the Act No. 40/1964 Coll., as amended - that have their own capacity as regards proprietary rights on the basis of which they dispose only with the property of the TSGU, not with their own property ${ }^{14}$ - were still perceived by the legislator as satisfactory. However, the reverse was soon shown to be true.

\footnotetext{
${ }^{13}$ By the way, this regulation itself did not turn out well just because it did not sufficiently respect the property rights related nature of these organizations. For details on this issue, see also pp. 126 to 128.

${ }^{14}$ For information on the nature of the problems related to this construction, compare with Havlan, P. (2000). Vlastnictví státu. Brno: MU, 183-188.
} 
In an effort to "bring" TSGU's contributory institutions "closer" to the comprehension of the traditional legal environment (where this legal entity after all represents a somehow atypical construction, i.e. a legal personality without the possibility to own), the legislator finally decided to proceed through partial adjustments that could be compared to a kind of "cloning" of the traditional model of the contributory institutions with some attributes (or rather their indications) of so-called traditional legal entities. With respect to the result of this legislative attempt (for details, see the text hereunder) it would apparently be more suitable if the legislator expressed, similarly as in the case of the central government's institutions receiving contributions from the central government's budget, the transitional character also for municipalities' and regions' contributory institutions and let them "decease" in their original form that, despite the fact that it does not meet the needs of the time and often seems hard to understand, has a clear logic and sense. What do the changes arising from Act No. 477/2008 Coll. really bring?

The amended act expressly stipulates that a territorial self-governing unit's contributory institution may obtain property to its ownership. In this way, the legislator probably wanted to eliminate long-lasting ambiguities (disputes) as regards the ownership capacity of these legal entities ${ }^{15}$. The amended act provides an enumerative list of the ways in which the contributory institution may obtain property to its ownership; however, this property must always be necessary for the performance of activities for which the institution was established. In brief: the contributory institution may obtain property to its ownership in principle only on condition that its founder "allows" it to do so. The amended act further develops this rather unusual construction (which relativizes the "ownership capacity" of the legal entity in question). The rule applies that in the event that a property that a contributory institution obtained through gratuitous transfer from its founder becomes permanently useless for an institution, it shall be obliged to offer it gratuitously to its founder. When the founder does not accept it, such a property in the ownership of a contributory institution may be transmitted to another entity upon the previous approval given by the founder and under the terms and conditions set by the founder. However, this rule shall not be applied to transfers of property in the ownership of a contributory institution in the event that it was obtained by it in another manner even though the previous written approval of the founder was required for this.

Generally, it still holds true that a contributory institution obtains property for its founder that is subsequently entitled to determine (in the deed of establishment of such an institution, in all probability) the cases when its previous written approval will be necessary for obtaining such a property. In cases where a founder reserves for itself its previous approval for obtaining a certain property, it shall be obliged to announce this in the Gazette of the Czech Republic in advance. The practicality of such a solution, especially with respect to the legal safeguard of entities entering into legal relations with a contributory institution does not seem to be ideal. Then, it gives a rather paradoxical impression (with respect to the new "ownership capacity" of TSGU's contributory institutions) when a contributory institution also obtains a property for its founder through transformation of its own

${ }^{15}$ For information on this issue, see, for example, Zprávy Ministerstva financí České republiky pro finanční orgány obcí a krajů, 2004(1). For opposing opinions, see Havlan, P. (2003). 
property, i.e. for example in the situation when it uses its own funds to acquire a thing and such a thing becomes a property of the institution's founder and the institution "only" performs the founder's ownership rights to the thing that were entrusted to the institution by the founder in the deed of establishment.

The granting of a founder's previous approval with some property-related acts to be executed by a contributory institution also gives a very problematic impression. With respect to the character of such previous approval - the decision about which will be taken, depending on the character of an intended act to be taken by a contributory institution, either by a municipal (regional) board in performing its functions of a founder (for example, in those cases where obtaining a property by a contributory institution to its ownership is conditioned by its founder's previous approval) or a municipal (regional) council if they are acts that would be subject to approval by a municipal (regional) council if they were executed directly by a municipality (region) and which are to be taken with the aim to obtain a property by a municipality (region) - new s. 39b of the so-called small budgetary rules (now s. 37b) provides for approximately as follows: a founder's previous approval shall always be granted for one legal act which it also makes a part of (here, the act on budgetary rules for territorial budgets plays the role of a specific act to the Civil Code that otherwise provides for essential elements of legal acts in general). This rule need not necessarily be effective in certain cases (see s. 39b (1) of the amended act - now s. 37b). If a contributory institution exercises a legal act which may be performed only on condition that a previous written approval has been issued for this as required by law or by a founder in a determined case (while s. 27 speaks about a "previous written approval", s. 39b (now s. 37b) speaks about a "previous approval"; however, it is obvious from the context that it is the same) without such approval, the legal act in question shall be null and void (by definition, it implies absolutely null and void).

The provision of s. 39b (2) (now s. 37b) of the latter regulation seems to be very disputable, as it stipulates that any previous approval may be additionally withdrawn until the moment when a legal act (i.e. a legal act to be executed by a contributory institution in which previous written approval is required for by law or the founder) becomes effective in case any material facts that were not known at the time of decision-taking and would have a substantial influence on the result of decision-taking emerge after such approval has been granted. This provision will cause a number of complications in future. This immediately begs several questions: for example, what are the "material facts", whether it will be possible to review such a decision about the existence of "material facts" or whether this will be de facto at a founder's discretion, whether and for how long will be a legal act executed by a contributory institution be valid, etc. The legislator probably did not rack his brains over issues concerning legal safeguard of the entities that a contributory institution will enter into legal relations with, not to mention whether the solution of the issues in question is conceptual. 


\section{Comments on the proprietary rights related nature of some other subjects operating in the sphere of territorial self-government}

\section{Associations of towns and municipalities}

With respect to proprietary rights, an association of towns and municipalities is some kind of a "transitional" form. It is an association sui generis (only municipalities may become its members), which is a legal entity liable for its obligations to the extent of all its property (see s. 49 (2) and (3) of the MO. Besides managing its own property, i.e. the property that it has obtained through its own activities, "an association of towns and municipalities manages the property that its member towns and municipalities put into the association of towns and municipalities from their own property under the statutes of the association of towns and municipalities"? while such property remains in the ownership of the respective town or municipality that put it "under the management of an association of towns and municipalities" (s. 38 (1) and (2), the first sentence of Act No. 250/2000 Coll.). In this case an association of towns and municipalities is in a position similar to that of a contributory institution (see s. 38 (2), the second and third sentence of the latter act).

Then, the fact that in both cases, i.e. as regards both property owned by an association of towns and municipalities itself and property of member towns and municipalities, it means, after all, the "public property" [i.e. to put it as briefly as possible, the property that belongs to a "public law entity", serving for a public purpose (see especially s. 50 (1) of the MO)] that is, in this case, managed by a corporate public law entity created by the will of other (member) entities of this type - a voluntary association of towns and municipalities (s. 46 of MO).

\section{Trading companies}

The circumstance that a territorial self-governing unit may also establish a trading company (joint-stock company or limited liability company) as a "type of TSGU's organization" (see the part under s. 23 of Act No. 250/2000 Coll.) has some contradiction in terms in itself. To put it simply: a public corporation (TSGU) puts its "public property" to a typically private law entity. At the same time, in the cases where a TSGU represents the only (100 percent) shareholder or partner, this private law entity or this private law "economic-law" form is in fact full of property of a "public character", it is "filled with public content". It is true that when a TSGU's property is put into such an entity, the property stops, strictly speaking, being the property of this public law entity and becomes the property of the trading company in question ${ }^{16}$; nevertheless, it is not possible to resign from the "public character" (as if the ownership was not the decisive criterion here) of the "ownership interest" of a TSGU ${ }^{17}$. Nevertheless, it is a pity that although some general obligations concerning managing a TSGU's property in the literal sense (see especially s. 38 (1) of the MO and s. 17 (1) of the RO) may be applied (by an extended interpretation)

\footnotetext{
${ }^{16}$ Fundamentally, it is usually a gratuitous transfer of things, including money (in the case of a monetary contribution) from the ownership of one entity to the ownership of another entity legally different from it.

17 This is so because significant rights of the TSGU in question are related to it, such as the right to a dividend, the right to a settlement share or the right to a share in the liquidation surplus.
} 
to disposing with ownership interests of a TSGU, a legal regulation providing for special rules on their disposing is lacking (for at least an idea on this matter, compare s. 28 (3) of Act No. 219/2000 Coll.), i.e. on disposing of this property by a TSGU in a broader sense. In this context, it is possible to express an opinion that, when there is any need of one hundred percent ownership interest of a TSGU in securing some economic activity, it would not be off the point to think about legislative enshrinement of the institute of the public corporation in the narrowest possible sense. ${ }^{18}$ This means a distinctive entity (a legal entity) that would have the full capacity to property rights (including the ownership capacity) and that would thus manage its own "public property" obtained both from its founder (the respective TSGU) upon its establishment and through activities during its existence. The enshrining of a corresponding mechanism of control of such an entity by its founding TSGU in law and provisions for other related issues goes without saying.

Of course, it would be possible to say all sorts of things about other entities considered by the acts regulating territorial self-government as well. For example, it would be necessary to count on more than one problem related to proprietary rights in the case of legal entities that may originate by virtue of s. 55 of the MO, or s. 28 of the RO, as the case may be, on grounds of cooperation with TSGUs of other countries where, in fact, a majority of issues will be ad hoc ones. However, this would be too great a digression from the proper objective of this paper, which really includes only the basic issues related to the topic, which is not easy in general, of territorial self-governing units as entities with proprietary rights of their own kind.

\section{Conclusion}

The above partial results indicate that the topics concerning the public property in question stand on the outskirts of the legislature's attention. The legislature insufficiently responds to the changes in society, the economy and the law itself. Special arrangements regulating the property in question became unlinked with the adjustment of private law. This leads to a wide range of application problems. This fact itself presents one of the risks the property of municipalities and regions is endangered with. Some of the concepts analyzed were found to be outdated or inconsistent with other parts of the legal order. Taking into account all the above-mentioned facts, the authors consider the hypothesis set out in the introduction to be confirmed.

It seems to be appropriate to finish by mentioning the decision issued by the Supreme Court of the Czech Republic on June 9, 1999, under file ref. 2 Cdon 1805/97, ${ }^{19}$ containing the following recital of law: "The metropolitan district of the capital city of Prague may not successfully claim the determination that it is the owner of a thing that passed to the possession of the municipality of the capital city of Prague pursuant to Act No. 172/1991 Coll." This means by referring to the judicial decision that uses the example of the "metropolitan district of the capital city" [which is an independent legal entity even according to

\footnotetext{
${ }^{18}$ Hendrych (2009).

${ }^{19}$ Sbírka soudních rozhodnutí a stanovisek (Collection of Judicial Decisions and Opinions), 2001(4), 238-243.
} 
the applicable legal regulation (s. 3 (2) of Act No. 131/2000 Coll., as amended by Act No. 145/2001 Coll., on the capital city of Prague); nevertheless, it does not have the ownership capacity (see s. 19 and s. 34 (3) and (5) of the quoted act), i.e. an entity which is not dissimilar to a contributory institution or, even more so, to the former budget organization as regards proprietary rights (s. 4 (3) of the quoted act $)^{20}$ ] illustrates quite well the practical results and connections of the basic issues related to proprietary rights that this paper has dealt with.

\section{Acknowledgements}

This paper was prepared with the financial support of the Czech Science Foundation (Project GAČR 13-30730S).

\section{References}

Havlan, P., Janeček, J. (2009). Public Property in the Czech Republic. Brno: Masaryk University.

Havlan, P. (2008). Veřejné vlastnictví v právu a společnosti. Prague: C. H. Beck. Havlan, P. (2003). Mohou př́íspěvkové organizace ÚSC vlastnit majetek? Právní zpravodaj: časopis pro právo a podnikání, 4(2), 12-13.

Havlan, P. (2001). Stát jako subjekt vlastnického a jiných majetkových práv v nové právní úpravě. Časopis pro právní vědu a praxi, (2), 123-129.

Havlan, P. (2000). Vlastnictví státu. Brno: MU, Brno.

Hendrych, D. et al. (2009). Správní právo. Obecná část (7th edition). Prague: C. H. Beck. Keller, J. (2003). K čemu jsou dobré kraje. Právo, 6.

Sbírka soudních rozhodnutí a stanovisek (Collection of Judicial Decisions and Opinions), 2001(4), 238-243.

Zprávy Ministerstva financí České republiky pro finanční orgány obcí a krajů, 2004(1).

\footnotetext{
${ }^{20}$ Contrary to city districts or metropolitan boroughs of the territorially divided chartered cities that are, as regards their property rights related nature, organizational sections or organizational units of the respective city (see s. 20 (2), s. 134, the first sentence, and s. 132 of the MO). On the other hand, as a certain expression of specificities of these districts and boroughs, compare also, for example, s. 133 of the MO, and, with respect to the metropolitan boroughs of the capital city, s. 18 (3) and (4) of the Act on the Capital City of Prague.
} 